\title{
Effective Competition and EU Competition Law ${ }^{1}$
}

\author{
Tuna Baskoy
}

\begin{abstract}
The notion of workable or effective competition is at the centre of EU competition law and policy, as it strives to achieve and maintain it. Some scholars do not mention it at all. Those who refer to it either do not explain it in any way or explicate it very shortly. In fact, the concept is too important to be ignored totally or elucidated briefly. The objective of this article is to provide a comprehensive analysis of the concept by focusing on the theory of workable or effective competition. It is argued that effective competition is the key for an in-depth study of the political economy (i.e. real policy goals, economic rationale behind individual competition rules, institutional requirements, and implications for distribution of wealth) of EU competition law and policy.
\end{abstract}

\footnotetext{
1 A longer version of this paper was presented at ECSA-C Conference, Canadian Perspectives on Contemporary Issues of European Integration, University of Victoria, Victoria, B.C., November 7-8, 2003. I would like to thank you very much for constructive criticisms as well as useful comments of conference participants and anonymous referees of this journal. All remaining errors and shortcomings are solely mine.
} 
The European Commission often perceives competition policy as the European Union's (EU) central public policy (CEC: 1997, p. 17). The EU does not see free market competition or a laissez-faire model premising on capitalist markets as a panacea to all problems due to self-destructive nature of market competition (CEC: 1958, p. 59). That is why competition rules were included in the European Economic Community (EEC) Treaty. As early as 1965, Hans von der Groeben, the first head of the European Commission's Directorate for Competition, maintained that one of the fundamental objectives of competition policy is "to establish an effective and workable competitive system” (CEC: 1966, p. 59).

In accomplishing this objective of introducing as well as maintaining effective competition, EU competition policy inhibits restrictive practices that fail to qualify for exemption (Article 81); proscribes abusive market conducts by dominant firms (Article 82); and prevents emergence of a dominant position that alters market structure significantly through mergers, acquisitions and merger-like joint ventures (the Merger Control Regulation or MCR). Moreover, it makes sure that public or private firms granted special rights by member states do not harm market competition (Article 86) and that state aids do not distort market competition (Article 87) (Korah: 2000).

With respect to administrating EU competition policy, Article 83 states that the Council of Ministers lays down the appropriate regulations and directives for implementing the principles in Articles 81 and 82 based on a proposal from the European Commission. Moreover, the Council of Ministers has extensive powers for implementing Article 87, as stated in Articles 88 and 89. Similarly, the European Commission has the power to implement Articles 81, 82, 86, and 87 as stipulated in Articles 85, 86 and 88. 
Moreover, the European Commission has the right to apply the MCR. National competition authorities and courts can implement Articles 81 and 82 only by following previous interpretation of them by the European Commission, the Court of First Instance (CFI) and the ECJ. In Moschel’s words, "Ultimately, the organs of the Member States mutate into auxiliaries of the Commission” (Moschel: 2000, p. 497). This brief account illustrates the fact that powers to implement EU competition law are centralized in the hands of EU institutions.

Being the central concept, workable or effective competition is ubiquitous in literature on EU competition law and policy as well as in official documents. Yet, surprisingly, it has not attracted the attention it deserves from students of EU competition law and policy. The objective of this article is to provide a comprehensive analysis of the concept of workable or effective competition. It is argued that an in-depth analysis of workable or effective competition unravels the economic and political rationale behind EU competition law and policy.

The first section provides a brief literature review, which is followed by the significance of effective competition in EU competition law in the second part. The third segment explains the theory of effective competition which was originally developed by John Maurice Clark in 1940, while the fourth and fifth subdivisions elaborate on how effective competition is helpful in understanding the inclusion of Articles 81, 82, 86 and 87 in the EEC Treaty and the exclusion of the MCR. The last section elucidates the reverberations of effective competition for institutional structure of the state and role of law in EU economic policy making and implementation. 
Review of European and Russian Affairs vol. 1 no. 1 December 2005 (C) JEURUS 2005 all rights reserved

\section{Literature Review}

It is widely acknowledged among the students of EU competition law and policy that effective or workable competition underlies the economic model behind EU competition policy (McLachlan and Swan: 1963; Cini and McGowan: 1998). In essence, three consistent patterns may be discerned in the literature regarding the treatment of effective competition. First, some scholars, for instance, do not mention the concept in their analysis at all (Petrella: 1998; Kemp: 1994; Fishwick: 1993; Swann: 1983). Rather, they discuss perfect and imperfect competition to elucidate the economic reason that justifies EU competition law.

Second, others maintain that EU competition law promotes and maintains workable or effective competition (Korah: 2000; van Gerven: 1974). Instead of elaborating the concept, they prefer to either silent or make broader generalizations without clarifying it in the first place. Finally, still others make a concrete attempt to explain the terms "effective" or "workable" competition, but their analysis is far from dispelling the mystery around the concept, as they use secondary resources on the concept (Lasok and Lasok: 2001; Carchedi: 2001; Goyder: 1998; Jacquemin and de Jong: 1977).

Not surprisingly, even EU institutions are not clear about what effective competition means to them. The ECJ defined workable competition in the Metro-SBGrossmarkte case as "the degree of competition necessary to ensure the observance of the basic requirements and the attainment of the objectives of the Treaty, in particular the creation of a single market achieving conditions similar to those of a domestic market” (ECJ: 1978, p. 2). Nonetheless, this definition is far from being clear. Veljanovski 
correctly states the problem as follows: "it is rare to find in EC antitrust texts, or in statements by the Commission, a clear expression of the nature of effective competition”(Veljanovski: 2004, p. 179). Therefore, there still remains a void both in the literature and the acquis regarding the meaning of effective competition. As a core concept in EU competition law and policy, it deserves to be explained in detail to dispel the confusion and ambiguity that surround it.

\section{Effective Competition and EU Competition Law}

Market competition plays a central role in the economic constitution of the EU (Sauter: 1998). Lindahl and van Roermund stress that "the core of EC [European Community] law consists in arranging, adapting, applying, and enforcing the default setting of competition, and which the ECJ [European Court of Justice] has elaborated by reference to what it terms 'workable competition'” (Lindahl and van Roermund: 2000, p. 15). The ECJ stated in the Hoffman-La Roche case that Article 3(f) of the EEC Treaty envisages the establishment as well as the maintenance of an effective competitive market structure (ECJ: 1979, p. 299).

Not surprisingly, Wilks and McGowan (1986) keenly observed that: "It is not too fanciful to suggest that European competition policy is one element determining the evolution of European capitalism, an element with a potential to take pre-eminence over other areas of Community law” (Wilks and McGowan: 1996, p. 226).In a nutshell, a comprehensive study of EU capitalism entails understanding its competition policy adequately which is not possible without elaborating on 'effective' or 'workable' competition. Astonishingly, neither the literature nor the acquis provides a coherent and 
consistent explanation for the rationale behind individual competition rules and their wording. It also has also a difficulty of explaining the motivation for the centralized enforcement of EU competition law. The best place to turn for satisfactory answers to these questions are is the theory of workable or effective competition.

\section{The Theory of Workable or Effective Competition}

John Maurice Clark was the first economist to develop the theory of workable or effective competition in 1940 (Clark: 1940). However, in revising his work, he decided to replace the concept 'workable’ with 'effective' in 1961, after realizing that the former had connotations that it is static (Clark: 1961). In the continental Europe, Clark’s theory found adherents amongst German Ordoliberals or the members of the Freiburg School who, in turn, played a crucial role in the preparation of the EEC Treaty (Bonefeld: 2002; Siems: 2002; Gerber: 1998).

There are three factors behind the development of the theory of effective competition. First, a capitalist market economy was producing instability, cartels and monopolies in the 1920s and 1930s. Second, it was not possible to reconcile the principal assumptions of perfect competition with the reality of economies of scale internal to the firm in the aftermath of theoretical developments in the field of economics (Clark: 1969, p. 488). Scale economies required large firms with significant market power that could be abused easily for realizing individual interests at the expense of social needs (Clark: 1960, p. 22). ${ }^{2}$ Finally, the capitalist market economy was in grave danger because of the economic depression of 1929 as well as the rising 'communist threat' (Clark: 1955b).

\footnotetext{
${ }^{2}$ Clark summarized the situation as follow: "To sum up, in a modern economy it has become impossible to trust an 'invisible hand' to turn crude self-interest into an efficient engine for meeting every social need" (Clark: 1955a, p. 14).
} 
It was clear by the 1930s that perfect competition was no longer a political ideal to be achieved under modern industrial conditions (Clark: 1969, p. 31). In response to theoretical developments in economic theory and historical evolution of capitalism, the theory of effective competition was put forward as a middle ground between perfect competition and monopolies (Keppler: 1994, p. 168). In particular, the theory was a pragmatic attempt to answer the negative public policy reverberations of the theories of imperfect and monopolistic competition such as excess capacity due to economies of scale, inefficient advertisement by monopolistic firms and market instability (Clark: 1961, p. ix).

As an attempt to incorporate dynamic analysis into the static neoclassical economic theory rather than totally overthrowing it, effective competition is a synthesis of the theories of monopolistic and imperfect competition with the vision of competition put forward by the Classical and Austrian schools of economics respectively (Markham: 1950). Not unlike the classical and Austrian theories of competition, effective competition is defined as "rivalry in selling goods" (Clark: 1940, p. 243). Indeed, it is pictured as a dynamic process, consisting of a series of 'gentle' competitive moves and responses (Clark: 1955b, p. 457).

These moves and responses appear in the form of independent activity in pursuit of higher profits or preventing a decline in profit (Clark: 1954). In aggressive and defensive forms, competition creates, reduces, eliminates and recreates profits in different sectors of the economy (Clark: 1955b, p. 454). In this regard, competition is a kind of 'neutralization process' in which the initial market power of the first mover is eradicated 
by the responding second firm, restoring the status quo ante in the market and eventually maintaining an equilibrium position.

In figuring out the real intent behind effective competition, the distinction between short-term and long-term analysis of competition within an industry is the key starting point. The underlying assumption in the theory of effective competition is that industry does not operate at full capacity or at a point where a marginal cost is equal to marginal revenue in the short run. Indeed, demand fluctuations cause the industry to operate below full capacity in the short-term in actual competition. If marginal cost is equal to average cost under such circumstances, there will be many bankruptcies. The solution to this problem in the short run is as follows:

..., the requirement is an individual demand curve with sufficient slope to bring price, on the average, far enough above marginal cost so that average cost may be covered, over the run of good times and bad. Along with this should go, presumably, enough price flexibility to afford a stimulus to demand in dull times, and the reverse in boom times (Clark: 1940, p. 250).

The theory of effective competition simply pronounces that the financial health of firms in the short term is the most important concern. Firms should have enough market power to make adjustments in prices according to changing market circumstances to assure their survival.

Compared to short-term curves, the theory assumes that long-run cost and price curves are much flatter as "long-run forces serve to mitigate the seriousness of the effects of imperfect competition” (Clark: 1940, p. 246). To be more precise, there is no immediate danger of bankruptcies. Potential competition and product substitution in the long-run are the principal factors that mitigate the slope of the curves and hence lessen effects of market power. Moreover, the long-run cost and price curves of commodities are much flatter than those of the short-run for two reasons. In the case of price curve, 
firms, instead of making profits in the short-run by increasing prices, maintain and improve their sales volume by sacrificing their immediate profits.

Concerning the cost curve, changes in capacity, not changes in output, within the physical capacity of an existing plant dominate firms’ long-run cost curves. Such costs do not vary significantly, if one considers the average optimum size of the firm. Certainly cost curves are much flatter (Clark: 1940, pp. 248-9). The theory of effective competition, therefore, is an attempt to reduce the discrepancy between immediate shortrun pressures and conditions of long-run equilibrium (Clark: 1940, p. 249).

After this explanation, it is not fancy to conclude that the theory of effective competition engenders a particular market environment where effective or 'gentle' competition can exist without ruining profit margins and causing market instabilities on the supply side. This particular market environment requires certain market structure and conduct. Put together, the required market structure and behaviour advocated by the theory of effective competition provides clues about the logic for the inclusion and wording of the competition rules in the EEC Treaty. It also explicates the exclusion of a competition rule dealing with mergers and acquisition in the Treaty.

\section{Effective Competition, Firms, and Articles 81, 82 and the MCR}

To survive short-term fluctuations in profitability, firms are presumed to have some degree of market power to affect price changes in effectively competitive markets. Effective competition requires high profit margins between prices and costs to stimulate demand in times of recession and do the reverse when the economy is booming. Thus, not every market structure is suitable for workable or effective competition 
(Sosnick: 1958). Effective competition requires a particular market structure where there are ‘enough’ number of players, depending on the dynamics of a particular industry (Shepherd: 1990, p. 16). In other words, effective competition engenders a moderate market concentration and loosely oligopolistic market structure (Sosnick: 1958, p. 419). This kind of market structure is perceived essential to prevent industry bankruptcies, besides providing firms a suitable environment for stimulating and curbing demand in accordance with changing market conditions.

It is not surprising that the Treaty of Rome did not have any competition rule that would prevent industrial concentration through mergers and acquisitions at the beginning, given there were so many firms in the newly opened EEC-wide markets. Nonetheless, increasing pace of market concentration in the late 1960s and 1970s and because of the limited juridical powers of Article 82 to deal with mergers and acquisitions, the European Commission submitted a proposal to the Council of Ministers in 1973 to regulate mergers and acquisitions with a Community dimension (CEC: 1974, p. 31). It took the Council 16 years to accept the proposal in 1989.

Given that effective competition requires loosely oligopolistic markets, there are usually firms, having a dominant market position. To have effective competition in place, it is necessary to assure that such firms do not abuse their dominant position by using any kind of unfair, exclusionary, predatory or coercive tactics against their competitors, suppliers or customers. That is the reason for the inclusion of Article 82 in the EEC Treaty that proscribes dominant firms abusing their market power. As it is clear from the language of Article 82, having a dominant position is legal, but abusing market power that accrues from such a position is illegal in EU competition law. 
Other market conditions for effective competition to flourish are price-sensitive quality differentials, free entry to the market, free access to information and some uncertainty about meeting price reductions are preconditions for effective competition, since a transparent and stable market environment causes an open or tacit collusion between firms (Asch: 1970, pp. 120-1). Free market entry is a key condition for effective competition, as it would put market pressure on firms thereby providing an incentive on the part of the firms to offer innovative, new and good-quality products (Sosnick: 1958, p. 418). Corporate conducts such as shielding of inefficient rivals or producers, and using tactics such as unfair, coercive, exclusionary and/or predatory and misleading sales promotion are harmful to effective competition (Asch: 1970).

As the extreme case, outright collusion is the most harmful market behaviour for effective competition (Clark: 1955b, p. 461). However, there are always exceptions against economic discrimination or restrictive practices. Cooperation and collaboration in every form such as interlocks, joint ventures and technological pools are legitimate, provided that they do not harm competition significantly and that they encourage efficiency and technological development which are thought to be beneficial to consumers in general (Sosnick: 1958, pp. 419-20). This explains the inclusion of Article 81 in the EEC Treaty as well as the rationale behind the wording of Article 81 which does not prohibit restrictive practices and cartels per se. Rather, it considers their benefits and costs on the basis of individual cases. On the whole, Articles 81 and 82 deal with firms competing in the market. 


\section{Effective Competition, Economic Role of the State, and Articles 86 and 87}

As it is clear from this brief account, there is little trust laid in market competition alone in allocating resources efficiently. Competition is not 'a simple and self-acting regulator that maintain[s] itself' without any outside help (Clark: 1961, p. 1). Effective competition can work only in certain markets and does not have power to correct significant market failures as “[t]he economist’s chief mechanism - the market cultivates certain kinds of needs and neglects others” (Clark: 1960, p. 10). In other words, the market is not trusted by itself because of the deleterious effects of effective competition and therefore is not seen as "a simple and self-acting regulator that can maintain itself” without any state intervention (Clark: 1960, p. 23).

The theory of effective competition attributes three major tasks to the state vis-àvis the market. The first function is to safeguard effective competition by regulating not only firm conduct, but also economic activities of states (Clark: 1961, p. 1). The second duty of the state is to correct market failures as well as to eliminate inefficiencies of effective competition by providing basic public goods, regulating the economy as well as pursuing stabilization, growth, and industrial policies. The final responsibility of the state is to pursue social goals through moderate fiscal redistribution (Clark: 1969, p. 168). ${ }^{3}$

This brief account of effective competition and the role of the state have two reverberations. First, despite its possible failures and negative consequences, theory of effective competition still defends market competition and puts it over everything else. Similarly, Article 86 subjects a revenue-producing monopoly to the rules contained in the EEC Treaty, especially to the rules of competition, as long as such rules do not prevent

\footnotetext{
${ }^{3}$ Underlying this theory, however, rests a fear that the welfare state may fuel high inflation that the Keynesian macroeconomic model carries within itself.
} 
the performance of the particular tasks assigned to public undertakings and privative firms to which the member states grant special or exclusive rights. Article 86 asserts the prevalence of market competition over anything else.

Second, state intervention indirectly and directly is justified in the theory of effective competition to correct market failures, provided that it does not distort market competition. As a form of indirect intervention, the insertion of the competition rules in the EEC Treaty serves this purpose. Additionally, Article 87 deals with direct state intervention, as it invalidates any aid granted by a member state or through state resources in any form that distorts or threatens competition by favoring certain undertakings or the production of certain goods, if it influences trade between the member states negatively.

Under Article 87, state aid permissible under three conditions. While, the first is whenever market forces obstruct progress towards the Treaty's objectives, the second is in situations where market forces prolong the period of attaining an objective of bringing cheaper and good quality goods and services or of bringing them at unacceptable social costs. Finally, whenever market forces intensify competition to such an extent that it can destroy itself, state aid is justified (CEC: 1965, p. 60).In brief, Article 86, along with Article 87, disciplines the state by controlling its activities in the market (CEC: 1973, p. 12). This is in line with what the theory of effective competition implies.

\section{Effective Competition, Institutional Structure of the State and Role of Law}

A system of effective competition entails "a framework of institutions as well as essential rules.” (Lenel: 1989, p. 29) A specific solution advocated by Franz Böhm, a 
prominent adherent of ordoliberalism, was the conception of an economic constitution (Moshel: 1989, p. 151). Walter Eucken , the founding father of ordoliberalism, defines the two underlying principles of the economic constitution, as constitutive and regulative (Eucken, 1950). With respect to the constitutive principle, institutional requirements necessary for the constitution to work comprise of the constitutional principles such as private property, a stable monetary system, freedom of contract, 'open’ markets, and personal liability for action. The regulative principles safeguard and maintain the system by preventing it from developing spontaneously in undesirable directions (Barry: 1989, pp. 114-5).

State intervention should be in the form of a few well-defined stabilizing measures. Since the economy consists of interrelated parts, frequent and arbitrary interventions in some spheres may have deleterious repercussions for other areas. This is essential for isolating economic logic from political pressures (Oliver, Jr.: 1960, pp. 1256). The only means to achieve this is law whose function is explained by Clark as follows: "In short, law is seen as an instrument of social control because it assures stability against frequent political interventions” (Clark: 1969, p. 123). This shows a strong tendency in the theory of effective competition that law is the main policy making instrument and few technocrats are the principal actors.

In short, the state is given the obligation to prevent the market system from destroying itself through stabilization, anti-monopoly and social welfare policies (Clark: 1969, p. 168). Naturally, the theory of effective competition entails a strong and isolated state: “The formula of 'strong state' was meant by them as shorthand for a state that is constrained by a political constitution that prevents government from becoming the target 
of special interest rent-seeking” (Vanberg: 1998, p. 178). Taken as a whole, the state has autonomy in making laws, as well as in daily administration. A regulatory state established on the basis of rule of law and market competition as a coordinator of activities in the market makes up the theoretical core of the theory of effective competition (Berhnholz: 1989, p. 190).

As such, the theory of effective competition has four major implications for political decision-making and organizational structure of the state. First, effective competition inevitably necessitates centralization of political power, augmenting decision-making power of the central authority at the expense of the lower levels of bureaucracy and citizens. Second, it requires technocratic decision-making by 'competent' top bureaucrats. Third, these bureaucrats should be free from political interventions and should be able to realize 'public' goals. Finally, objectives of the general public, rather than parochial political concerns, should be the guiding factor behind the actions of these bureaucrats (Clark: 1969, pp. 490-1).

As a result, effective competition requires specific institutional structure and organizational form which has negative implications for democracy, as political power is gathered in the hands of few, while citizens are excluded from participating in political decision making. Nonetheless, such negative results of the strong state for democracy in return for gains in efficiency in the economic and political spheres are accepted:

If the state is strengthened against such pressures, something of what we are accustomed to think of as democracy may be lost. Bureaucracies and centralized executive power and responsibility grow. But there is no reason to think we must go all the way to dictatorship in order to make control reasonably effective; in fact, we may lose little that we now have of the substance of popular control over government and its activities (Clark: 1969, p. 494). 
In other words, effective competition requires a trade-off between economic and political efficiency and democracy. Economic and political efficiency, rather than democratic participation, is the source of legitimacy for the polity in the theory of effective competition.

This brief account of the institutional requirements of effective competition and the role of law in policy making process substantiate an observation by Majone, an eminent student of European integration that the main function of law in the EU is to keep economics as separate as possible from politics by isolating the former from the latter as well as disciplining the latter (Majone: 1998). In this sense, the legal debate has become a fully autonomous factor in the political process in the process of European integration (Dehousse: 2000, p. 17).

In particular, the primary function of law is to work as a mask for politics, creating a functional sphere for circumventing the direct clash of political interests. Dehousse succinctly describes the role of law in policy-making as follows: "Partisan conflict is transformed into allegedly non-partisan questions about the proper interpretation of the treaty.” (Dehousse, 1998, p. 115) Debating and deciding important political outcomes in the language and logic of law conceals as well as alters political conflicts to a certain extent, resulting depoliticization of political decision-making and juridification of politics (Burley and Mattli, 1993, p. 44). As such, law replaces 'conflicts of interests' with 'matters of principles' and depoliticizes the political process. This also explains why the European Parliament is still not the main legislative institution. 


\section{Concluding Remarks}

It has been demonstrated that the theory of effective competition provides a set of relevant criteria with the aim of providing guidance on the competitive nature of markets, thereby serving as a guide to the formulation and implementation of competition policy. ${ }^{7}$ As such, the theory of workable or effective competition has six major implications for the design of the EU competition rules and their administration. First of all, assuring profitability of firms is the main goal of EU competition law and policy. Second, loosely oligopolistic markets which are free from restrictions and abusive practices are the ideal market environment for effective competition to exist as well as flourish.

Third, effective competition is not against restrictive practices or cartels per se, in that if they are beneficial to consumers and do not restrict competition significantly, they can be tolerated. Fourth, market competition has priority over everything else in the market, including firms granted special rights to provide general public services. Fifth, the state is attributed significant responsibilities to correct market failures through both direct intervention and indirect regulation. Finally, the theory of effective competition requires centralized political power and technocratic decision-making, and law is attributed a significant role to play in economic policy making and implementation.

Because of space limitation, this essay did not deal with major flaws of effective competition. The next task to be accomplished is to identify the major flaws regarding the vision of effective competition and analyze EU competition law cases to figure out how they become manifest in EU competition law decisions. This will provide concrete clues for improving EU competition law and policy. 


\section{Bibliography}

Asch, P. Economic Theory and the Antitrust Dilemma, (New York: John Wiley \& Sons, Inc. 1970).

Barry, N. P. "Political and Economic Thought of German Neo-Liberals," in Peacock, A. and Willgerodt, H. eds., German Neo-Liberals and the Social Market Economy, (New York: St. Martin’s Press, 1989).

Bernholz, P. "Ordoliberals and the Control of the Money Supply," in A. Peacock and H. Willgerodt, eds., German Neo-Liberals and the Social Market Economy, (New York: St. Martin's Press, 1989).

Bonefeld, W. "European Integration: The Market, the Political and Class,” Capital \& Class, No. 77 (2002), pp. 117-42.

Burley, A-M. and Mattli, W. "Europe before the Court: A Political Theory of Legal Integration,” International Organization, Vol. 47, No. 1 (1993), pp. 41-76.

Carchedi, G. For Another Europe: A Class Analysis of European Economic Integration, (Verso, 2001).

CEC. First General Report on the Activities of the Community, (Brussels: The Publications Department of European Communities, 1958).

Eighth General Report on the Activities of the Community, (Brussels: The Publications Department of European Communities, 1965).

. Ninth General Report on the Activities of the Community, (Brussels: The Publications Department of European Communities, 1966).

. Second Report on Competition Policy, (Brussels-Luxembourg: Office for Official Publications of the European Communities, 1973).

. Third Report on Competition Policy (Brussels-Luxembourg: Office for Official Publications of the European Communities, 1974).

. XXVIth Report on Competition Policy 1996, (Brussels: Office for Official Publications of the European Communities, 1997).

Cini, M. and McGowan, L. Competition Policy in the European Union (St. Martin's Press, 1998).

Clark, J. M. “Toward a Concept of Workable Competition,” American Economic Review, Vol. 30, No. 2 (1940), pp. 241-56. 
. "Competition and the objectives of government policy," in Chamberlin, E. H. ed., Monopoly and Competition and Other Essays: Paper and Proceedings of a Conference Held by the International Economic Association, (New York: St. Martin’s Press, 1954).

. The Ethical Basis o Economic Freedom, (Westport, Connecticut: The Calvin K. Kazanjian Economics Foundation, Inc., 1955a).

. "Competition: Static Models and Dynamic Aspects," American Economic Review, Vol. 45, No. 2 (1955b), pp. 450-62.

. Alternative to Serfdom, (New York: Vintage Books, 1960, $2^{\text {nd }}$ Ed.).

. Competition as a Dynamic Process, (Washington: Brookings Institution, 1961).

Ed.).

Social Control of Business, (New York: Augustus M. Kelley Publishers, 1969, $2^{\text {nd }}$

Dehousse, R. The European Court of Justice: The Politics of Judicial Integration, (New York: St. Martin's Press, 1998).

"Integration through Law Revisited: Some Thoughts on the Juridification of the European Political Process," in Snyder, F. ed., The Europeanization of Law: The Legal Effects of European Integration, (Oxford: Hart Publishing, 2000).

ECJ. Metro-SB-Groß-Märkte GmbH \& Co. KG v. EC Commission, (Case 26/76), Common Market Law Reports, Vol. 22, No. 2 (1978), pp. 1-62.

. Hoffman-La Roche \& Co. AG v. Commission of the European Communities (Case 85/76), Common Market Law Reports, Vol. 26, No. 3 (1979), pp. 211-344.

Eucken, W. The Foundations of Economics: History and Theory in the Analysis of Economic Reality, (London: William Hodge and Company Limited, 1950).

Fishwick, F. Making Sense of Competition Policy, (Lodon: Kogan Page Limited, 1993).

Gerber, D. Law and Competition in the Twentieth Century Europe: Protecting Prometheus, (Oxford: Clarendon Press, 1998).

Goyder, D. G. EC Competition Law, (Oxford: Oxford University Press, 1998, $3^{\text {rd }}$ Ed.).

Jacquemin, A. P.and de Jong, H. W. European Industrial Organization, (New York: John Wiley \& Sons, 1977).

Kemp, J. “The competition policy of the European Union,” in McDonald, F. and Dearden, S. eds., European Economic Integration, (London: Longman, 1994). 
Keppler, J. Monopolistic Competition Theory: Origins, Results, and Implications, (Baltimore: The John Hopkins University, 1994).

Korah, V. An Introductory Guide to EC Competition Law and Practice, (Oxford: Hart Publishing, 2000, $7^{\text {th }}$ Ed.).

Lasok, K. P. and Lasok, D. Law and Institutions of the European Union, (London: Butterworths, 2001, $7^{\text {th }}$ Ed.).

Lenel, H. "Evolution of the Social Market Economy," in Peacock, A. and Willgerodt, H. eds., German Neo-Liberals and the Social Market Economy, (New York: St. Martin’s Press, 1989).

Lindahl, H. and van Roermund, B. "Law without a State? On representing the Common Market,” in Bankowski, Z. and Scott, A. eds., The European Union and its Order: The Legal Theory of European Integration, (Oxford: Blackwell Publishers, 2000).

Majone, G. “Europe’s 'Democracy Deficit': The Question of Standards,” European Law Journal, Vol. 4, No. 1 (1998), pp. 5-28.

Markham, J. W. "An Alternative Approach to the Concept of Workable Competition,” American Economic Review, Vol. 40, No. 3 (1950), pp. 349-361.

McLachlan, D. L. and Swan, D. “Competition Policy in the Common Market', Economic Journal, Vol. 73, No. 289 (1963), pp. 54-79.

Moschel, W. "Competition Policy from an Ordo Point of View," in A. Peacock, and H. Willgerodt, eds., German Neo-Liberals and the Social Market Economy, (New York: St. Martin's Press, 1989).

Moschel, W. "Guest Editorial: Change of Policy in European Competition Law," Common Market Law Review, Vol. 37, No. 3 (2000), pp. 495-9.

Oliver, Jr., H. M. “German Neoliberalism,” Quarterly Journal of Economics, Vol. 74, No. 1 (1960), pp. 117-49.

Petrella, R. “The Limits of European Union Competition Policy,” New Political Economy, Vol. 3, No. 2 (1998), pp. 292-5.

Sauter, W. "The Economic Constitution of the European Union,” Columbia Journal of European Law, Vol. 4, No. 1 (1998), pp. 27-68.

Shepherd, W. G. The Economics of Industrial Organization, (Englewood Cliffs, NJ: Prentice Hall, 1990, $3^{\text {rd }}$ Ed.). 
Siems, M. M. “Shareholders, Stakeholders and the 'Ordoliberalism'," European Business Law Review, Vol. 13, No. 3 (2002), pp. 139-51.

Sosnick, S. H. “A Critique of Workable Competition,” Quarterly Journal of Economics, Vol. 72, No. 3 (1958), pp. 380-423.

Swann, D. Competition \& Industrial Policy in the European Community, (Methuen, 1983).

Vanberg, V. J. "Freiburg School of Law and Economics," in P. Newman, ed., The New Palgrave Dictionary of Economics and the Law, Vol. 2, (London: Macmillan, 1998).

Van Gerven, W. “Twelve Years EC Competition Law (1962-1973) Revisited,” Common Market Law Review, Vol. 11, No. 1 (1974), pp. 38-61.

Veljanovski, C. "EC Merger Policy after GE/Honeywell and Airtours,” Antitrust Bulletin, Vol. 49, No. 1/2 (2004), pp. 153-93.

Wilks, S. and McGowan, L. "Competition Policy in the European Union: Creating a Federal Agency?,” in Doern, G. B. and Wilks, S. eds., Comparative Competition Policy: National Institutions in a Global Market, (Oxford: Clarendon Press, 1996). 